\title{
Lean philosophy and its applications in the service industry: a review of the current knowledge
}

\author{
Higor dos Reis Leite ${ }^{a *}$, Guilherme Ernani Vieira ${ }^{b}$ \\ a*UFTPR, Curitiba, Brazil, higor@utfpr.edu.br \\ ${ }^{b} P U C P R$, Curitiba, Brazil
}

\begin{abstract}
This article presents an in-depth bibliographic study about the creation, principles, evolution, and practices of the lean philosophy oriented to the services sector. More than 70 papers about "lean thinking" - specially with focus on services - have been carefully reviewed. It presents the principles of lean service in an organized way, companies applying lean service, and best practices and tools in the implementation of lean service. It shows that lean service does not have a single or specific model of tools, practices or standards. In fact, it is a mix of tools and practices that must be applied according the situation found to be improved. Despite the lack of a standards and methodology for use in services, its best practices, inherited from manufacturing, when applied to services can generate large economic and financial results, as well as improvement of workers' behavior. But, like any change process, this study shows that the application of lean in services also suffers resistance. There might be limitations when evaluating lean practices and principles to services, specially those that have not yet been well defined and reported. Other limitations are due to the scarce articles in the literature. However, this research showed that the use of the lean philosophy in services proved to be effective and quite worthwhile. Several cases analyzed presented significant gains and confirmed an increasing and promising future for service companies "thinking lean".
\end{abstract}

Keywords

Lean service. Service performance improvement. Waste elimination. Lean philosophy.

\section{Introduction}

The lean philosophy (lean thinking, lean manufacturing or Toyota Production System) were developed by the Japanese in the mid 50's, and is nowadays worldwide used by companies. The term "lean thinking" encompasses a set of lean practices and was first proposed by Womack et al.(1992). From the advent of the lean concept to the present days, the popularity of lean thinking has spread exorbitantly. Earlier applications only focused on manufacturing companies (therefore the resulting designations: lean manufacturing or lean production). The lean thinking philosophy, however, quickly moved to new areas such as services, trade and the public sector (Womack \& Jones, 2005). Even with this expansion to new areas, the major use of lean thinking is still little spread among other areas. And hence the availability of literature specific with lean applied to the service sector is still scarce (Piercy \& Rich, 2008b). The lean transformation to the manufacturing sector is well established, however, the use of lean tools to improve service quality is relatively new, with limited reported benefits and approaches.

Therefore, there is still a great need for new strategies and technologies to the service sector, despite the fact that it accounts for over half of the gross domestic product (GDP) and employment of most modern economies. Specifically, according to Fortes (2010), the service industry accounts for $58 \%$ of the world's GDP and in the beginning of this millennium, in the United States, professions related to services amounted to $79 \%$ of total employment. Since 2008, more that 55\% of Brazil's GDP is generated by services (IBGE - Brazilian Institute of Geography and Statistics).

This article has two focuses. First, it intends to conduct a literature review on the history of lean 
service. Secondly, it analyzes important topics related to the development of lean service, such as, where publications are being made, researchers involved with this subject, main contributions and principles of lean to the service areas, focus on the customer, companies applying lean service, most important the results being reported, the areas applying lean service and best practices specific to lean service.

For a better understanding of the research conducted, the article was divided into four sections, namely: introduction, history and evolution of lean production and services, development of the lean service (including volume of annual publications, researches, principles, aplications, uses, best practices) and closing remarks.

\section{History and evolution of lean production and services}

According to a study conducted by Cerioli (2009), the services sector has already demonstrated its relevance as an economic activity since classical Greece, when young people received education. Subsequently, other service activities were developed, such as spices and textiles transportation through the silk route during the low Middle Age (Correa, 2006). Since then, the service sector developed strongly until the first industrial revolution, when it lost its economic importance, regaining it only in the twentieth century. Thereafter, it has maintained a steady growth, gaining increasing importance, both in developed and emerging countries.

Today, the service sector stands out for being responsible for the largest share of the world's GDP and for creating jobs and wealth that grow at higher rates than in other sectors of the economy (Table 1). Some factors such as urbanization, demographic changes, socioeconomic changes, increased sophistication and technological changes have contributed to ensure that services reached this level of importance in society.

Currently, services are considered the center of economic activity, being one of the pillars of economy, as well as mining, agriculture and manufacturing. According to Cobra (2004), there are five particularly important service sub-groups: a) Business: consulting, finance, banks, etc. b) Commercial: retail, maintenance, repairs, etc. c) Infrastructure: communications, transportation, etc. d) Social and personal: restaurants, supermarkets, health, etc. e) Public administration: education, government, etc. Besides being essential in generating jobs, service companies are also responsible for supporting the major types of industrial, commercial and agricultural activities.
Table 1. Percentage of the services sector in the world's largest economies in year 2005 (Adapted from Sarkar, 2007).

\begin{tabular}{ccc}
\hline Number & Country & \% service setor in GDP \\
\hline 1 & USA & 78.7 \\
2 & Japan & 72.5 \\
3 & Gemany & 69.5 \\
4 & China & 40.0 \\
5 & United kingdon & 75.8 \\
6 & France & 76.4 \\
7 & Italy & 68.8 \\
8 & Spain & 66.5 \\
9 & Canada & 68.4 \\
10 & Brazil & 51.0 \\
11 & South Coreia & 52.0 \\
12 & India & 54.0 \\
13 & Mexico & 70.0 \\
14 & Russia & 57.0 \\
15 & Australia & 75.0 \\
\hline
\end{tabular}

In the mid-eighteenth century, with the advent of industrial revolution in England, the world market was flooded with machinery and equipment, which increased the production of products on a large scale. Mass production is a term that means large-scale production of standardized products by means of serial assembly lines. This mode of production was expanded and improved by Henry Ford in the early twentieth century, particularly in the production of the vehicle Ford Model T. Mass production has become a widespread mode of production, considered bestin-class at the time, because it allowed high rates of output per worker and at the same time generated products at low prices.

According to Dennis (2008), the traditional mass production had its problems. Workers hated it: no one wanted to be in a factory. Unions fought constantly to reduce work hours. Many works of art satirized mass production, including Charlie Chaplin in his classic movie Modern Times. But mass production could not be applied to all plants and thus, the Japanese, in particular the Toyota car factory, had to develop their own model, which would be called the Toyota Production System (lean production or lean manufacturing). Shingo (1996) cites the Toyota Production System as a process of continuous waste elimination. After World War Il, the Japanese industry had a very low productivity and huge lack of resources, which, of course, prevented it from adopting the mass production model.

Dennis (2008) defines waste with the Japanese word "muda", the opposite of value, which is simply what a customer is willing to pay. It is also common to see the definition of seven wastes that the lean philosophy seeks to eliminate are: a) overproduction, the largest source of waste; b) waiting time, refers to 
materials that are waiting in queues to be processed; c) unnecessary transportation that does not generate added value to the product; d) unnecessary processing, some operations of a process could not exist; e) inventories, their reduction will occur through their root cause; f) motion; g) defects, producing defective products means waste materials; h) manpower, handling of defective materials and others. Recently a new (eighth) waste has been introduced: the misuse of intellectual capital Womack \& Jones (2003). This waste means not stimulate or use the complete employee capacity in identify opportunities for improvement.

Lately, Bowen \& Youngdahl (1998) proposed a framework that depicts the convergence of manufacturing production to services (Figure 1). Levitt (1972) was one of the first authors to study the transfer of organization principles applied to production lines for manufacturing systems towards services. His studies were based on the fact that the services sector could benefit from the techniques developed by manufacture.

Based on the studies of Levitt $(1972,1976)$ and additionally taking advantage of the emergence of the fundamentals of lean production (Ohno, 1997), researchers Bowen \& Youngdahl (1998) were the first to carry out studies about the transfer of the lean production techniques used in industries to the services sector. They conducted case studies of applications of lean tools and published the results of what became known as lean service. This study presented the characteristics of the lean service applied in a network of fast food restaurants, in a hospital and an airline company. The results of these studies led to new applications in lean service and further

\begin{tabular}{|l|}
\hline \multicolumn{1}{|c|}{ Manufacturing - Line Production } \\
\hline - Outputs and tangibles results \\
- Outputs and standard results \\
- Inventory management focus \\
- Limited operators autonomy \\
- High inventory of final products \\
- High Capital Assets \\
\hline
\end{tabular}
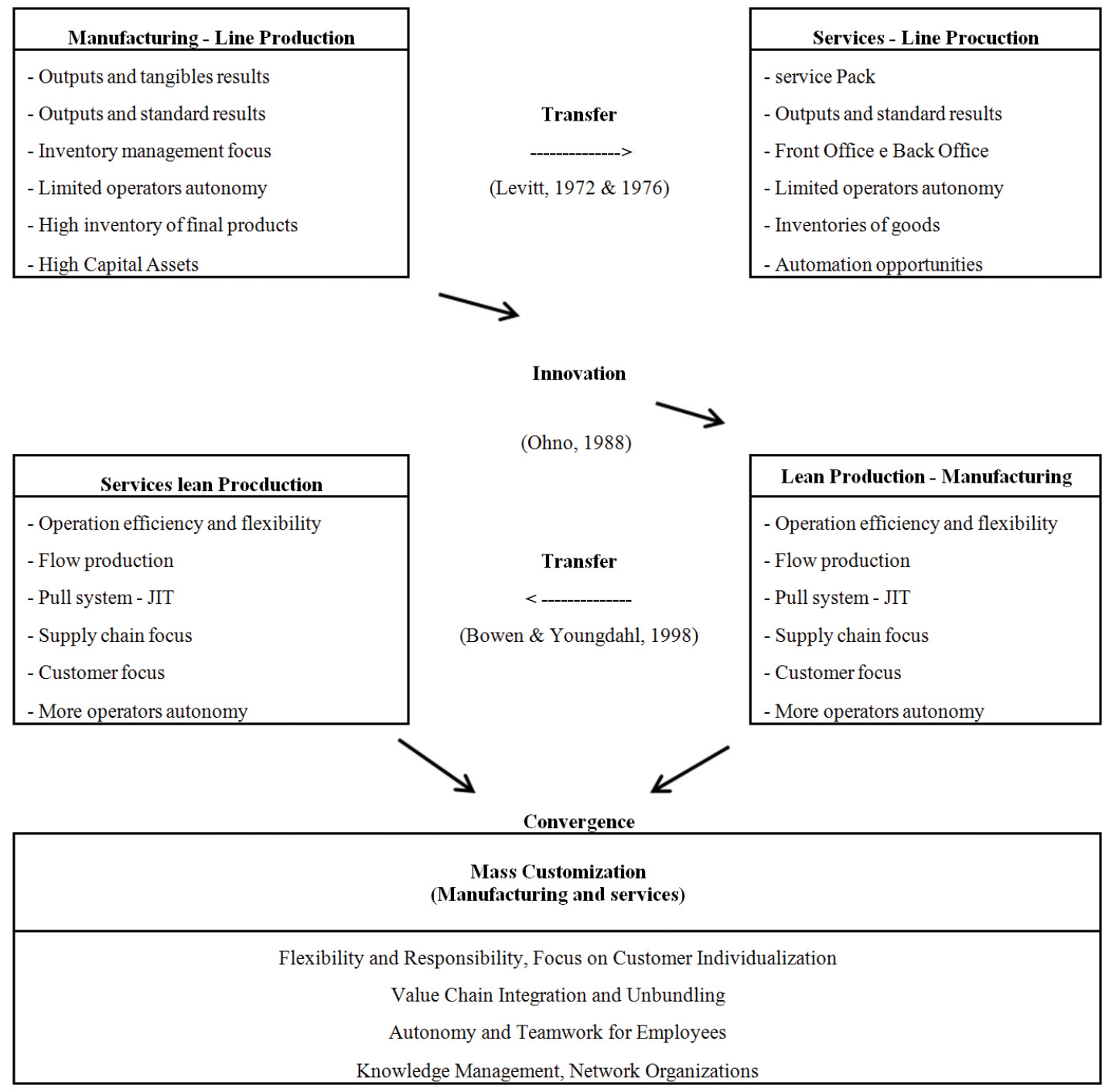

Figure 1. The Convergence of services and guidelines of manufacturing production (Bowen \& Youngdahl, 1998). 
studies by other authors, which will be demonstrated later in this paper.

\section{Analyzis of important topics related to lean service}

Since its first real appearance as lean service (Bowen \& Younghal, 1998), when it began to be considered as a new model of services production, and until present days, the concept of lean service received several reviews and suggestions for improvements and applications. This part of the study analyzes the main contributions, results, principles and companies that are applying lean service, areas more interested in lean service, best practices and tools "adapted" to lean service.

\subsection{Researches and main contributions}

To allow a better understanding of the evolution of lean service, it is important to understand its origins, evolution and the main contributions during its evolution. Table 2 summarizes the main authors and their contributions to the area of lean service. Presented in chronological order, it is possible to evaluate the early transfer of manufacturing techniques to services (Levitt, 1972), as well as, applications in other services areas.

Just as lean manufacturing and lean Six Sigma are models that have creators or people who have become a reference for creating and defending such models, with this research it is possible to state that authors Bowen \& Youngdahl (1998) can be considered as the "fathers" of lean service. In their seminal article "Lean service: in defense of a production-line approach", the

Table 2. Researchers and main contributions to the lean service sector.

\begin{tabular}{|c|c|}
\hline Author & Main Contribution \\
\hline Levitt (1972) & Transfer of manufacturing logic to service operations. \\
\hline Bowen \& Youngdahl (1998) & First lean approach in services with case study and definition of the characteristics of lean service \\
\hline Allway \& Corbett (2002) & Similarity between the techniques used in manufacturing and services, as well as lean service principles. \\
\hline Swank (2003) & Through case study proved that the use of lean principles can improve performance. \\
\hline Apte \& Goh (2004) & Case study with applications of lean thinking in information-intensive services. \\
\hline Cuatrecasas (2004) & Case studies using lean tools that reduced cycle time and increased efficiency (2002 and 2004). \\
\hline Ahlstrom (2004) & Presentation of concepts of lean service and restrictions on their application. \\
\hline George (2004) & Definition of the wastes in service operations \\
\hline Sánchez \& Pérez (2004) & Validation of the study by Ahlstrom (2004), by means of indicators that measure the lean service application level. \\
\hline Womack \& Jones (2005) & A six-step model to solve the customer problems and use of a consumption map. \\
\hline Venkat \& Wakeland (2006) & Use of simulation tools to analyze process optimization in the service sector \\
\hline Francischini et al. (2006) & Analysis of waste under the customer's and the company's perspectives, plus five case studies analyzed. \\
\hline Abdi et al. (2006) & $\begin{array}{l}\text { Establishes that the most important element in the service sector is the human variable. Presenting lean's } \\
\text { characteristics. }\end{array}$ \\
\hline Liker \& Morgan (2006) & Using the principles of the Toyota model with an effective integration of people, processes and technology. \\
\hline Maleyeff (2006) & One of the first models of lean oriented towards the companies' internal services and seven wastes in services. \\
\hline Arruda \& Luna (2006) & Lean principles applied to services and seven wastes applied to services. \\
\hline Sarkar (2007) & A book with the DEB-LOREX model, using five elements: people, processes, partners, promotion and troubleshooting. \\
\hline Giannini (2007) & Adaptation and Application of lean tools in back office and front office services, through a case study. \\
\hline Bicheno (2008) & First book to present a set of tools for lean service. Fourteen office wastes. \\
\hline Lee et al. (2008) & The relevance of IT tools, once they support lean systems during implementations. \\
\hline Piercy \& Rich (2008b) & Applicability of lean techniques in a service environment with three case studies in service companies. \\
\hline Araujo et al. (2009) & $\begin{array}{l}\text { Demonstrated the existence of a synergy between the evidence-based medicine and lean thinking to the } \\
\text { promotion of medical practice quality and efficient process management. }\end{array}$ \\
\hline Staats \& Upton (2009) & A case study in a software provider that used lean to improve its operations. \\
\hline Song et al. (2009) & List of service-oriented lean tools and each type of service may require different tools. \\
\hline Julien \& Tjahjono (2009) & Presented a case study with the implementation of lean tools in a Safari Park \\
\hline Selau et al. (2009) & A case of use of lean principles in a hospital using the process mapping tool. \\
\hline Seddon \& O’Donovan (2010) & Review of lean concepts, where lean has become synonymous with "efficient process". \\
\hline Asif et al. (2010) & $\begin{array}{l}\text { A case study with several challenges for lean implementation and reductions in waste, as well as the need to } \\
\text { develop specific indicators for services. }\end{array}$ \\
\hline Portioli-Staudacher (2010) & $\begin{array}{l}\text { Statements that lean techniques are being implemented in high volume, but low variety of processes and } \\
\text { focus on back office activities. }\end{array}$ \\
\hline Bortolotti et al. (2010) & Carrying out a process mapping and then automation in the activity that adds value to the customer. \\
\hline Fortes (2010) & lean techniques applicable to IT processes \\
\hline
\end{tabular}


term lean service was created and gained prominence for being the first approach of the lean philosophy oriented to the services area.

Levitt (1972) was responsible for the kickoff in studies of transfer of techniques used in manufacturing to the service sector, but still totally oriented to mass production, which is entirely justified, since production at that time had only this focus.

Following this line of new studies about lean services, Allway \& Corbett (2002) presented situations that proved that it is possible to use manufacturing techniques in services, as well as new definitions for lean principles. Later, Swank (2003) consolidated some of lean service results performing a case study of applications of lean in a financial application.

Bicheno (2008) and Song et al. (2009) presented two "toolboxes" for lean services implementations. Their models present a set of lean tools that can be applied to production processes and, if properly used, should bring good results for the operation of services.

\subsection{Principles of lean service}

The lean manufacturing philosophy, strongly disseminated by Taiichi Ohno, is based on principles that guide the "lean thinking". According to Womack \& Jones (2003), the principles of lean manufacturing are five, namely: value specification, value stream mapping, flow optimization, pull production system and perfection or continuous improvement.

For Nascimento \& Francischini (2004), the definition of lean service is a standardizable system of service operations made up only by activities that generate value for customers, focusing on explicit tangibles and aiming to meet the customers' expectations for quality and price.

For Bowen \& Youngdhal (1998), the great similarity with the Womack's model is to generate production flow process in services and also use pull systems by the customer. However, another important contribution by these authors is the human factor involved in the process, when they suggest the use of "empowerment" for employees and teams. The service sector, differently from industries, has a great involvement of people, whether in customer service (front office) or in preparing something that should be delivered to a distributor or even directly to the customer at the point of sale (back office). This is evidenced by Chase \& Apte (2006) who reported that in 2006, the service sector in the United States had $83 \%$ of the workforce while manufacturing had only 10\%. Lean service principles must be improved: focused on low cost customer, easy process standardization, co-production and information technology accepted by the customer.

Lean principles applied to the service sector and focused on employees, whether in training or in increase of their autonomy (empowerment), were studied by Bowen \& Youngdahl (1998), Swank (2003), Sarkar (2007) and Bicheno (2008), reinforcing the importance of the human factor in the process of delivering services.

Besides focusing on people that make part of the transformation process, lean service also focuses on the customer. Unlike manufacturing, the first contact for selling service is the customer. The service company deals with the customer directly on the front line, differently from most industries. According to Silvestro et al. (1992) there are three different categories in service sector. First, professional service with high focus on people, contact time and process, as an example of this category is a corporate bank. Second, service shops as hotel or rental service with medium focus on customization and front office and back office; this category which falls between professional and mass services with the levels of the classification dimensions falling between the other two extremes. The last one is mass service with low attention to equipment and customization, a great example is the transportation service.

For Womack \& Jones (2005) for a correct use of lean in services it is necessary to apply important principles, such as: completely solve the customers' problems by ensuring that all services operate and, especially, work together, and do not waste the customers' time, provide exactly what they want, exactly where and when wanted. Maister (1985) also suggested two "service laws": the first compares customers expectations with their perceptions of service delivery - if the perceived service is better than the expectations, they turnout to become happy customers. The second law states that the first impression can influence the rest of the service consumption experience. Based on this statement, there are two fundamental variables in the relationship of service delivery:

- customers being the first, and

- the employees who deliver the service.

In manufacturing operations, high costs and focuses are related to raw materials and equipment, but in service operations, manpower is one of the most relevant factors in the cost of doing the job. Abid et al. (2006) argues that the human element is a highly relevant variable in the services sector.

Despite the similarity of some lean service principles and lean manufacturing, lean service does not have a single or specific model that can be taken as reference 
in any situation or area of service like standard steps, on the contrary, there are several models which can be applied according to the nature of the service. Such statement can be justified by the broad variation of the nature of services. For instance, there are services related to hospitals, logistics, food production, food consumption, air transport of passengers or cargo, information technology and so on. Table 3 shows a list of characteristics found in lean service for each author who has done in his/her research.

\subsection{Lean Service: focus on the customers and on time}

The service area, differently from the manufacturing area, strongly depends on human factors, which is responsible for the prospection, execution and delivery of service to the customer, who expects service with high quality.

In a recent study (Lean Solutions), Womack \& Jones (2005) introduced the concept of the "Lean Consumption". The idea is not that the customer shops less but shops with less difficulty and disruption. In this context, companies should adopt practices to eliminate inefficiency in production processes, and it is now the moment to take initiatives to deliver consumption experience more efficiently and with less sacrifice. The principles of Lean Consumption described by Womack \& Jones (2005), are summarized in the Table 4.

Table 3. Lean principle for services - Adapted from Selau et al. (2009).

\begin{tabular}{|c|c|}
\hline Author & Lean characteristics developed to service operation \\
\hline $\begin{array}{c}\text { Bowen \& } \\
\text { Youngdahl (1998) }\end{array}$ & $\begin{array}{l}\text { - Reduce the performance trade-offs } \\
\text { - Make the value-added processes flow and implement customer-driven system } \\
\text { - Eliminate losses in the value chain of activities, from development to delivery } \\
\text { - Increase customer focus and involvement in the development and delivery processes } \\
\text { - Empower employees and teams }\end{array}$ \\
\hline Swank (2003) & $\begin{array}{l}\text { - Reduce the performance trade-offs } \\
\text { - Make the value-added processes flow and implement customer-driven system } \\
\text { - Eliminate losses in the value chain of activities, from development to delivery } \\
\text { - Increase customer focus and involvement in the development and delivery processes } \\
\text { - Empower employees and teams } \\
\text { - Segregate activities by complexity } \\
\text { - Publish / present performance results }\end{array}$ \\
\hline $\begin{array}{l}\text { Sánchez \& } \\
\text { Pérez (2004) }\end{array}$ & $\begin{array}{l}\text { - Elimination of losses } \\
\text { - Continuous improvement } \\
\text { - Multifunctional teams } \\
\text { - Just-in-time delivery } \\
\text { - Involvement of suppliers } \\
\text { - Flexible information systems }\end{array}$ \\
\hline Ahlstrom (2004) & $\begin{array}{l}\text { - Elimination of waste } \\
\text { - Zero defects } \\
\text { - Pull instead of push } \\
\text { - Multifunctional teams } \\
\text { - Decentralization of responsibilities } \\
\text { - Verticalized information systems } \\
\text { - Continuous improvement }\end{array}$ \\
\hline $\begin{array}{l}\text { Womack \& Jones } \\
\qquad(2005)\end{array}$ & $\begin{array}{l}\text { - Solve the customers' problem completely by ensuring that all services } \\
\text { operate and work together } \\
\text { - Do not waste the customers' time } \\
\text { - Provide exactly what customers want } \\
\text { - Provide what is wanted, exactly where wanted } \\
\text { - Provide what is wanted, where wanted and when wanted }\end{array}$ \\
\hline Jones (2006) & $\begin{array}{l}\text { - Specify what creates and what does not create value from the customers' perspectives } \\
\text { - ldentify all the steps needed to design, order and produce the service along the } \\
\text { flow to focus on losses that do not add value } \\
\text { - Make those activities that create value flow without interruptions, return or fragments } \\
\text { - Do only what is driven by the consumer } \\
\text { - Strive for perfection, continuously improving services and value stream }\end{array}$ \\
\hline Sarkar (2007) & $\begin{array}{l}\text { - Application of the DEB-LOREX model showing all the organizations' processes and ensuring sustainability. Use of } \\
\text { five elements: people, processes, partners, troubleshooting and promotions. }\end{array}$ \\
\hline Bicheno (2008) & $\begin{array}{l}\text { - The new wastes: making the wrong product to be efficient, human capital, inappropriate systems, energy and } \\
\text { water and natural resources. } \\
\text { - Seven wastes in customer service: delays, duplication, unnecessary movement, lack of clarity in communication, } \\
\text { wrong inventory, missed opportunities and mistakes. } \\
\text { - Fourteen office wastes: screening and research, inappropriate measurement, low load, high load, inappropriate } \\
\text { prioritization, interference, inappropriate frequency, startup and end off, mistakes, errors or lack of appropriate } \\
\text { knowledge, communication error, sub-optimization, wait, improper presence and inappropriate tradeoff. }\end{array}$ \\
\hline
\end{tabular}


Table 4. The principles of Lean Consumption (Womack \& Jones, 2005).

\section{Principles of Lean Consumption}

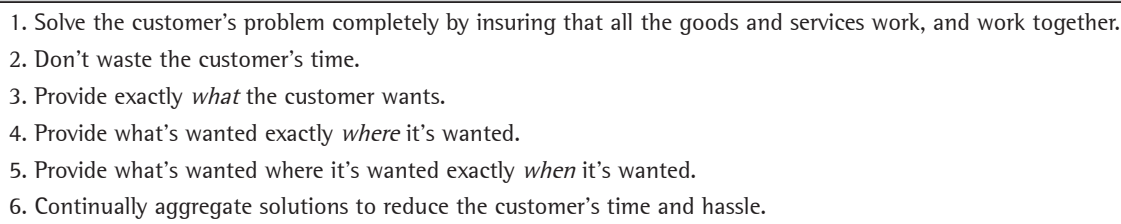

Although these principles were created having the final consumer in mind, they are perfectly adaptable for all kinds of customers since companies belong to a supply chain. Any supplier or customer can be targeted to receive lean initiatives. In a companyto-company relationship, some examples reinforce the use of lean initiatives. If a company examines its inbound process, for instance, it can find ways to not waste driver's time and supplier's vehicles with inbound and outbound activities. A furniture manufacturer, for example, knows that it should not delivery tables alone, even if the factory was not able to manufacture chars on time.

The lean service operations must offer what customer wants, where he wants it. Supermarkets build branches (stores) where customers are and connect them through distribution centers - strategically located. This increases speed and agility on the product distribution. It is easy to see that these retailers are using large supermarkets (megastores) located out of downtowns, regular supermarkets in neighborhoods, small markets are spread for all city, and on-line markets for internet sales.

Lean logistics must be up-to-date with new techniques to increase performance (especially delivery time) and customer satisfaction. Suppliers should understand the customers' needs, apply lean methodologies to their processes and adapt themselves to customers. But often this is a two-way highway. Customers and suppliers should be strategically and operationally aligned (Chopra \& Meindl, 2004).

Currently, there is a saying well know in airlines companies: low cost/low fare. The focus is to reduce aircraft time on ground. For this, customers are partially involved in some activities to reduce this time, for example, just before landing, the crew requests all passengers to collect their trash and magazines. Besides reducing ground time it help reduce expenses with cleaning. Another lean logistics strategy at airports is the boarding time. Passengers located at different portions of the aircraft are called at different time intervals.
In hospitals, lean is applied to reduce the waiting time. They have rules and procedures specific to different types patients and procedures, such as for first aid, surgery, tomography, X-ray, lesions, and etc. Lean logistics in this business form team responsible to precisely identify each case, quality performance indicators are used to help find possible problems, and surgery tools, tomography equipments, rooms needed.

\subsection{Companies applying lean service and main results}

Once analyzed the principles of lean service, a second step is a study to verify the companies that have been using the lean philosophy in services and the improvements being obtained. Around twenty-five companies were studied, from large fast food chains, financial groups, hospitals to a safari park (Table 5).

Bowen \& Youngdahl (1998) presented Taco Bell fast-food chain as an example of lean implementation in services. Results can be described as based on tradeoffs between efficiency and operations with low cost and flexibility, thus increasing human resources management and focus on customer and on quality.

Another company that had significant improvements and should be highlighted in this analysis is Jefferson Pilot Financial Insurance Company (Swank, 2003). Applying the principles of lean production, the insurance company improved its operation and increased revenues, reduced order processing time by $70 \%$, labor costs by $26 \%$, and error reduction around $40 \%$.

The improvements, reductions and gains are not only financial results when applying the principles of lean service, but also positive reflections on quality perveived by clients (Table 5). This is the case of the LifeCare Hospital, which reduced infections caused by transfusion by $70 \%$. There were also gains for the Hospital "Pólo do Pé Diabético" that eliminated unnecessary movements of patients, combined flexibility and efficiency, reduced processing time with improved quality and productivity. 
Table 5. Lean service companies and their results with lean principles.

\begin{tabular}{|c|c|}
\hline Company & Improvements Obtained Using lean service \\
\hline Taco Bell & $\begin{array}{l}\text { One of the first companies on record to apply lean service and solve its "tradeoffs" between efficiency } \\
\text { with low cost operations and flexibility. }\end{array}$ \\
\hline Southwest Airlines & $\begin{array}{l}\text { Elimination of services costs, flow and speed of service delivery, and creation of a service experience } \\
\text { for customers. }\end{array}$ \\
\hline Shouldice Hospital & $\begin{array}{l}\text { Cost reduction, remarkable recovery rates of patients, greater availability of operating rooms and } \\
\text { hospitalization. }\end{array}$ \\
\hline Jefferson Pilot Financial Company & $\begin{array}{l}\text { Improved operation and increased revenue. Reduced by } 70 \% \text { the time of processing a request, } 26 \% \text { the } \\
\text { cost of labor and } 40 \% \text { for errors. }\end{array}$ \\
\hline Grupo Fernando Simão & $\begin{array}{l}\text { Extended the time of customer's value aggregation from } 53 \% \text { to } 94 \% \text { and its operations extended the } \\
\text { time of adding value from } 27 \% \text { to } 50 \% \text {, while reducing costs by } 30 \% \text {. }\end{array}$ \\
\hline Fugitsu services & $\begin{array}{l}\text { Reduced calls relating to customer complaints by } 40 \% \text { and specifically for complaints of printer } \\
\text { malfunctioning by } 80 \% \text { in } 18 \text { months, improving customer satisfaction and reducing operating costs } \\
\text { with the delivery of new printers. }\end{array}$ \\
\hline Tesco Retailer & $\begin{array}{l}\text { Reached a level of service above } 96 \% \text { becoming the market leader in its segment in the United } \\
\text { Kingdom. }\end{array}$ \\
\hline Wal-Mart & Eliminated the need to hold the stocks in the back of the store or in a warehouse. \\
\hline Zara & $\begin{array}{l}\text { It offers a wide variety of clothing, but avoid large inventories and counting on a quick response to } \\
\text { the market. }\end{array}$ \\
\hline LifeCare Hospital & $87 \%$ reduction in infections caused by transfusion. \\
\hline Monongahela Valley Hospital & Dramatic reduction in infections. \\
\hline UPMC Health System & Dramatic reduction in infections. \\
\hline Allegheny General Hospital & Dramatic reduction in infections. \\
\hline HISCO Inc. & Significant reduction of costs, savings on storage space, reduction of labor costs. \\
\hline Lotte- Mart. & Significant cost savings by outsourcing logistics. \\
\hline MC Donald's & Developed processes to ensure quality. \\
\hline Disney Theme Parks & Developed processes to ensure quality. \\
\hline Pólo do Pé Diabético & $\begin{array}{l}\text { Reduction of trade-offs of performance combining flexibility and efficiency, reduced processing } \\
\text { time with improved quality and productivity. Elimination of non-value added activities, eliminating } \\
\text { unnecessary displacement of patients and reducing the number of hospitalizations. }\end{array}$ \\
\hline Hospital Pró-Cardiáco & $\begin{array}{l}\text { Reduction of trade-offs of performance combining efficiency and flexibility. Elimination of non-value } \\
\text { added activities. }\end{array}$ \\
\hline Hospital Dr. Badim & $\begin{array}{l}\text { Reduction of trade-offs of performance combining efficiency and flexibility. Elimination of activities } \\
\text { that do not add value by improving efficiency and agility. }\end{array}$ \\
\hline Hospital Copa D’Or & $\begin{array}{l}\text { Reduction of trade-offs of performance combining efficiency and flexibility. Elimination of non-value } \\
\text { added activities, reducing pharmacy costs. }\end{array}$ \\
\hline Diagnóstico da América & $\begin{array}{l}\text { Reduction of trade-offs of performance combining efficiency and flexibility. Elimination of non-value } \\
\text { added activities. }\end{array}$ \\
\hline Wipro Technologies & Not informed \\
\hline WSP Park Safari & Inventory reduction, improved animal welfare and improved customer satisfaction. \\
\hline Hospital de Clínicas de Porto Alegre & $\begin{array}{l}\text { Presented a series of possible improvements to be implemented in the process, with strong potential } \\
\text { for applicability of the principle of waste elimination. }\end{array}$ \\
\hline
\end{tabular}

It is possible to verify that the use of lean service principles are rapidly appearing in several companies in different areas of activities. Results are increasingly tangible to the organization and often intangible to customers.

\subsection{Areas that most have applied lean service}

Due to diversity of service sector, the principles of operation management and market practices are difficult to be defined in service companies (Chase \& Apte, 2006). Nevertheless, some authors have presented models to define actions within the service area, for example, Lovelock (2001), who argued about focusing on specific service categories and proposed five schemes for classifying services, from services classes to delivery methods. In order to define the areas of possible services action, Schmenner (1986) suggested the use of a matrix with four classes of service: manufacturing services, shopping services, mass services and professional services. This matrix has great relevance, helping define and implement the best lean service tool (or principle) to specific service class.

Some areas within the service sector that have mostly applied lean principles are health, finance sector, banks and insurance. The health sector, mainly with hospitals, is the area that have mostly applied lean principles. According to Araujo et al. (2009), health services have many sources of inefficiency and quality problems that are a real challenge for managers in the area. Generaly a hospital can be seen as a large 
company with multiple services in it, for example, drug pharmacies, warehouses, restaurants, safety, lobby and patients release area, surgical centers, hotels and others. The potential for improvement in service quality and cost reduction is enormous in the healthcare area.

Other areas that deserve attention are the financial sector and banks, which are institutions with large volumes of document processing and analysis, prone to mistakes and/or rework. This is an area that acts with a market that can generate immediate profits or losses and where competition is rapidly acting upon customers. An example is a process to finance a vehicle: the customer shops and the financial institution has only a few minutes to approve or not the credit, but during this time, a series of information must be collected and analyzed.

Lean service enters with its principles acting in control, autonomation, agility and continuous improvement, ensuring the process a considerable stability and continuity. Similarly to the financial sector, the insurance area also has a high turnover of processes and approvals within its activities, and perhaps that is why lean service, seeking to improve the work process, has been highly studied within these organizations. Table 6 sums up some of the service areas using lean philosophy in their processes.

\subsection{Best practices and tools applied to lean service}

It is important to know the tools that are being adapted and applied to lean service. For better detailing, besides checking all the tools, Table 7 shows implementations of the four most commonly used tools: value stream mapping (VSM), production balancing (heijunka), just in time (JIT) and 5S standardization. For a common comprehension of the lean tools, the research addressed tool as a group of techniques developed and applied from the lean philosophy, these tools applied to lean service are quickly explained next.

To learn about the current state of operation and to propose further improvement, it is first necessary to carry out the value stream mapping in the production process applied to services, because this way it is possible to view all stages in the process. For Rother \& Shook (1999), a value stream is all action (adding value or not) required to bring a product through all flows essential to each product: production flow from raw material to the hands of the consumer, and the flow of product design, from conception to launching. Even in the service sector, the application of value stream maps is of great relevance, because most of the companies mentioned by the authors used VSM to improve processes because, similarly to manufacturing, the service sector also has direct relation with development, preparation and delivery of service to customers, and these steps, activities or processes are easily mapped using VSM concepts.

Production balancing ("heijunka") is one of the pillars of the Toyota Production System. It leads to efficient resources use, inventory reduction, downtime and high and high costs elimination, hence directing the creation of processes flexibility. Using a balanced operation helps a company to develop new ways of better buying from suppliers, better use of equipment, and more efficient use, inclusion of new processes and better team planning. Without balancing production is not possible to achieve JIT.

Practical applications of production balancing in services are seen in hospitals (setting the correct patients flow through service and surgeries), in restaurants (avoiding disruptions and delays in serving meals), in the financial sector (balancing the distribution of credit approval processes), and so on.

Next tool is JIT that is more considered an effect caused by the application of several tools. According to Slack et al. (2002), just in time is a paced technique, aiming at improving global productivity and eliminating waste. It comes as a consequence of the use of a balanced production. The customer will have his needs met on time and only for what is needed (it is a pull system, triggered by demand). JIT allows organizations to deliver services more efficiently and with reduced costs, since it intends to provide just the right amount, at the right time, at the place determined and using the minimum capacity from facilities, equipment, materials and people. JIT has a number of tools and techniques that provide operating conditions, such as Kanban (Slack et al., 2002).

Another tool often mentioned in the literature is the use of standardization and 5S. Although it may seem something that is already inherent in organizations, this is one of the issues organizations end up not paying much attention to and, in fact, this is one of the tools that will ensure that the obtained improvement can stay stable. Especially in service areas with expressive movement of people and materials, standardization and $5 \mathrm{~S}$ can help ensure process stability.

Something relevant about these tools is the fact that they are all connected to the pillars of the Toyota Production System's house, which demonstrate that the use of the same tools applied to manufacturing should also be used in the services sector. A summary of tools that have been applied to lean service is given at Table 7 . 


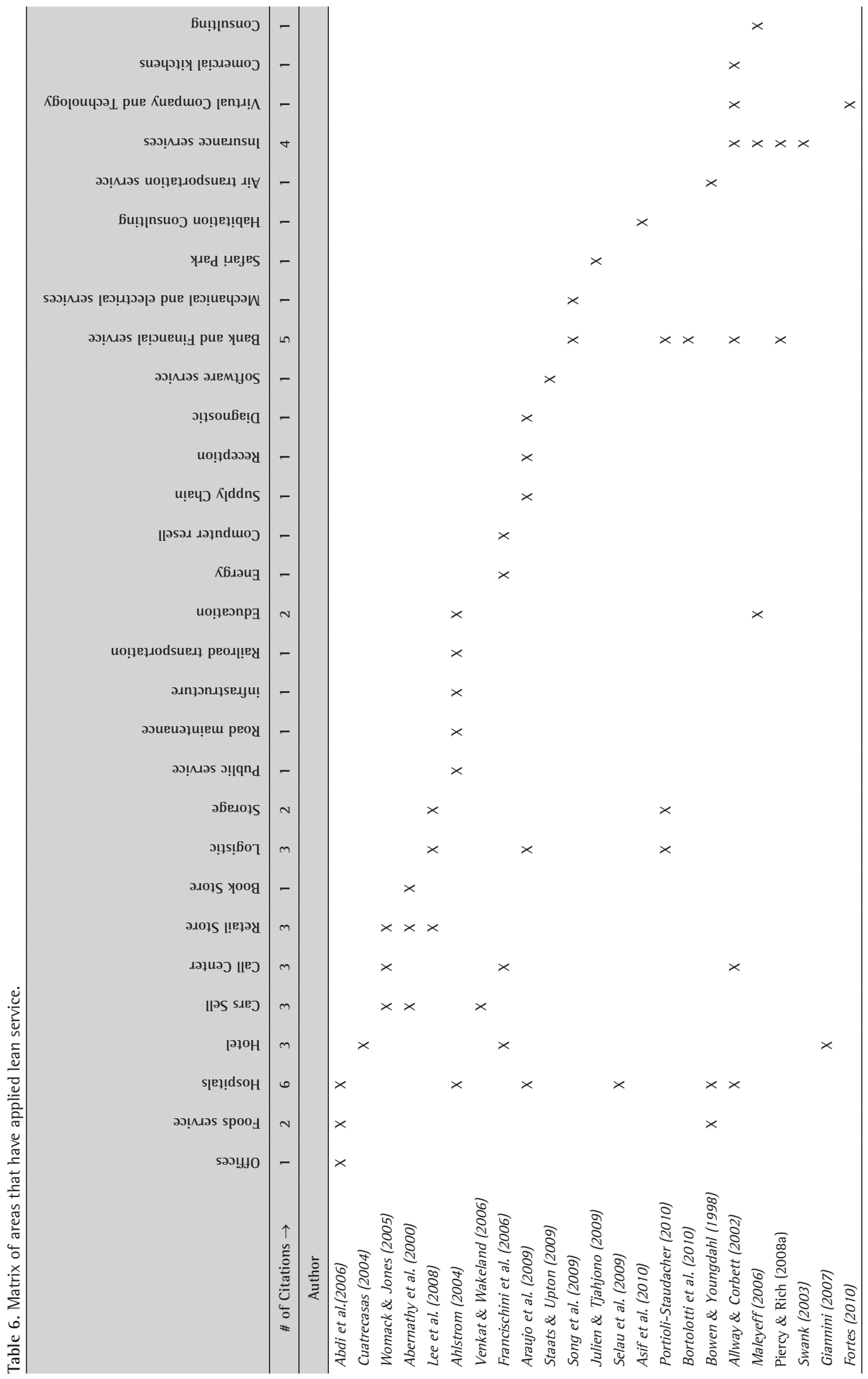




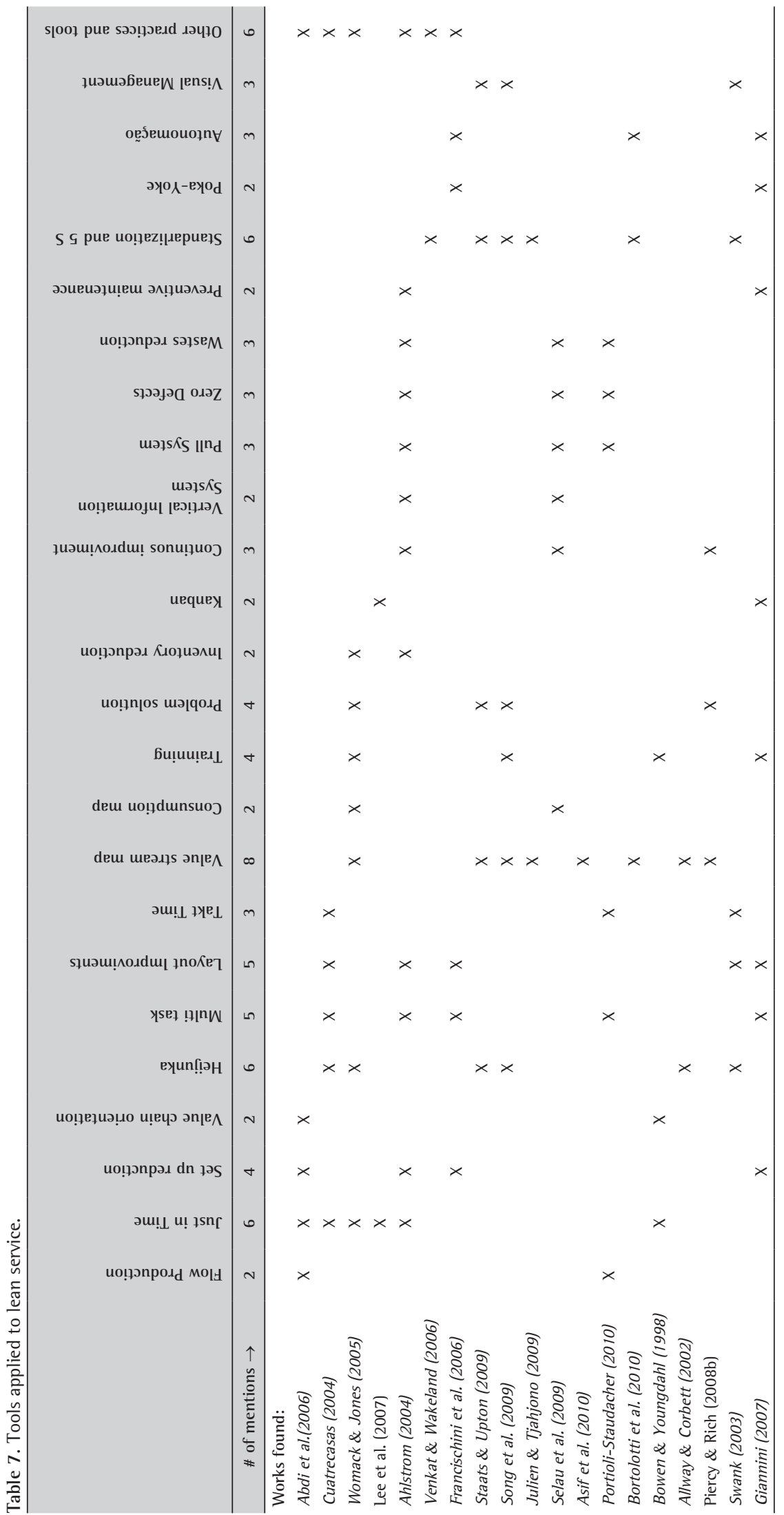




\section{Concluding remarks}

This article is one of the first known researches to present a bibliographic study about the creation and evolution of lean service, with principles and practices oriented to the services sector. A major benefit of this work was to present what are the principles of lean service in an organized way, the companies that are applying lean service and the best tools and practices applied in the implementation of lean service.

By analyzing the results, it can be said that lean does not have a single model of tools or practices and standards for services. It can be noticed that each author uses a "mix" of tools and practices that in their opinion best serves in an operation, this is, a collection of the best practices applied to specific needs of a company and its line of services.

Despite the lack of a standard set for which, when and where to use a lean tool in services, it can be seen that the best lean manufacturing practices, when applied to services, can generate large economic and financial results, as well as in the behavior of people. Obviously, like any change process, the applications of lean in services also suffer high resistance to their application. However, as shown in some articles, and specifically by Swank (2003), this is another barrier to be overcome that if not treated with care will compromise the operation. But successfully attracting those who have been resistant to the lean thinking will become a factor that in time will be favorable to new lean implementations. The results cannot pass unnoticed.

Despite possible limitations, one can affirm that lean philosophy in services has proved to be very positive. In fact, none of the works researched mentioned significant drawbacks or brought suggestions to not implement lean in business services. On the contrary, several cases in service companies showed large success obtained with lean practices and principles - and at increasing rate of implementations.

Future researches shall study in more details each business service sector to where lean has been (or can be) applied. Areas such as health, government (public administration), logistics, offices, teaching, retail and others have been applying lean practices. One can now do a specific study in each of these areas and translate the benefits from one service area to another. Perhaps even propose an implementation methodology, for each specific area and/or to "services in general".

\section{References}

Abdi, F., Shavarini, S. K., \& Seyed Mohammad, S. H. (2006). Glean lean: how to use lean approach in service industries?. Journal of services Research, 6, 191-206.

Abernathy, F. H., Dunlop, J. T., Hammond, J. H., \& Weil, D. (2000). Control your inventory in a world of lean inventory. Harvard Business Review, 78(6), 169-176. PMid:11184971.

Ahlstrom, P. (2004). Lean service operations: Translating lean production principles to service operations. International Journal of services Technology and Management, 5(5-6), 545-564. http://dx.doi. org/10.1504/IJSTM.2004.006284

Allway, M., \& Corbett, S. (2002). Shifting to lean service: Stealing a Page from Manufactures' Playbooks. Journal of Organizational Excellence, 21(2), 45-54. http://dx.doi. org/10.1002/npr.10019

Apte, U. M., \& Goh, C. (2004). Applying lean manufacturing principles to information intensive services. International Journal of services Technology and Management, 5(5-6), 488-506. http://dx.doi.org/10.1504/ IJSTM.2004.006280

Araujo, C. A. S., Figueiredo, K. F., \& Silberstein, A. C. (2009). Princípios Enxutos Aplicados em Serviços: Cinco Casos Brasileiros. In Anais do Simpósio de Excelência em Gestão e Tecnologia.

Arruda, I. M., \& Luna, V. M. S. (2006). Lean service: a abordagem do lean System aplicada no setor de serviços. INEGEP.

Asif, M., Lowik, S., Weusthof, W., \& Bruijn, E. J. D. (2010). Challenges in lean Implementation in KnowledgeIntensive services. In Proceedings of the International Manufacturing Symposium, Cambridge.

Bicheno, J. (2008). lean Toolbox for service Systems. England: lean Enterprise Research Centre, Cardiff Business School and University of Buckingham.

Bortolotti, T., Romano, P., \& Nicoletti, B. (2010). Lean First, Then Automate: An Integrated Model for Process Improvement in Pure service-Providing Companies. IFIP Advances in Information and Communication Technology, 338, 579586. http://dx.doi.org/10.1007/978-3-642-16358-6_72

Bowen, D. E., \& Youngdahl, W. E. (1998). Lean service: in defense of a production-line approach. International Journal of Service Industry Management, 9(3), 207-225. http://dx.doi.org/10.1108/09564239810223510

Cerioli, D. (2009). As Atividades de Serviços. Universidade Estadual do Oeste do Paraná. Retrieved from http:// www.unioeste.br.

Chase, R. B., \& Apte, U. M. (2006). A history of Research in service Operation: What's the big ldea. Journal of Operations Management, 25, 375-386. http://dx.doi. org/10.1016/j.jom.2006.11.002

Chopra, S., \& Meindl, P. (2004). Gerenciamento da Cadeia de Suprimentos: Estratégia, Planejamento e Operação. Ed. Pearson.

Cobra, M. (2004). Serviços: como construir valor para o cliente. São Paulo: Marcos Cobra.

Correa, H. L. (2006). Gestão de serviços: lucratividade por meio de operações e de satisfação dos clientes. São Paulo: Atlas. 
Cuatrecasas, L. (2004). A lean management implementation method in service operation. International Journal of services Technology and Management, 5(5-6), 532-544. http://dx.doi.org/10.1504/IJSTM.2004.006283

Dennis, P. (2008). Produção lean simplificada. Porto Alegre: Bookman.

Fortes, C. S. (2010). Aplicabilidade de lean service na Melhoria de Serviços de Tecnologia da Informação (TI) (Dissertação de mestrado). Universidade Federal do Rio Grande do Sul.

Francischini, P. G., Miyake, D. 1., \& Giannini, R. (2006). Adaptação de conceitos de melhorias operacionais provinientes do lean Production em operações de serviços. In Anais do Encontro Nacional de Engenharia de Produção

George, M. L. (2004). Lean Seis Sigma para Serviços. Rio de Janeiro: Qualitymark.

Giannini, R. (2007). Aplicação de Ferramentas do Pensamento Enxuto na Redução de Perdas em Operações de Serviços (Dissertação de mestrado). Escola Politécnica, Universidade de São Paulo, São Paulo.

Jones, D. T. (2006). lean in Delivering services. Lean Summit 2006. São Paulo.

Julien, D. M., \& Tjahjono, B. (2009). Lean Thinking Implementation at a safari park. Business Process Management Journal, 15(3), 321-335. http://dx.doi. org/10.1108/14637150910960585

Lee, S. M., Olson, D. L., Lee, S., Hwang, T., \& Shin, M. S. (2007). Entrepreneurial applications of the lean approach to service industries. Service Industries Journal, 7-8, 973987.

Levitt, T. (1972). Production-line approach to service. Harvard Business Review, 50(5), 20-31.

Levitt, T. (1976). The Industrialization of service. Harvard Business Review, 54(5).

Liker, J. K., \& Morgan, J. M. (2006). The Toyota Way in services: The Case of lean Product Development. Academy of Management Perspectives, 5-20. http:// dx.doi.org/10.5465/AMP.2006.20591002

Lovelock, C. (2001). Serviços: Marketing e Gestão. São Paulo: Saraiva.

Lovelock, C. H. (1983). Classifying services to gain strategic marketing insights. Journal of Marketing, 47, 9-20. http://dx.doi.org/10.2307/1251193

Maister, D. H. (1985). The psychology of waiting lines. In J. A. Czepiel, M. R. Solomon \& C. F. Suprenant (Eds.), The service Encounter: Managing Employee/Customer Interaction in service Business. Lexington: Lexington Books. PMid:4037768.

Maleyeff, J. (2006). Exploration of Internal service Systems Using lean Principles. Management Decision, 44(5), 674689. http://dx.doi.org/10.1108/00251740610668914

Nascimento, A. L., \& Francischini, P. G. (2004). Caracterização do Sistema de Operações de Serviço Enxuto. PIC-EPUSP, n. 2.

Ohno, T. (1997). O Sistema Toyota de Produção: além da produção em larga escala. Porto Alegre: Artes Médicas.

Piercy, N., \& Rich, N. (2008a). High quality and low cost: the lean service centre. European Journal of Marketing, 43(11-12), 1477-1497.
Piercy, N., \& Rich, N. (2008b). Lean Transformation in the pure service environment: the case of the call service centre. International Journal of Operations \& Production Management, 29(1), 54-76. http://dx.doi. org/10.1108/01443570910925361

Portioli-Staudacher, A. (2010). Lean Implementation in services Companies. IFIP Advances in Information and Communication Technology, 338, 652-659. http:// dx.doi.org/10.1007/978-3-642-16358-6_81

Rother, M., \& Shook, J. (1999). Aprendendo a Enxergar Mapeando o fluxo de valor para agregar valor e eliminar o desperdício. Lean Institute Brasil.

Sánchez, A. M., \& Pérez, M. P. (2004). The Use of lean Indicators for Operations Management In services. International Journal of services Technology and Management, 5(5-6), 465-478. http://dx.doi.org/10.1504/ IJSTM.2004.006278

Sarkar, D. (2007). Lean for service Organizations and Offices: a holistic approach for achieving operational excellence and improvements. American Society for Quality.

Schmenner, R. W., 1986. How can service businesses survive and prosper. Sloan Management Review, 27(3), 21-32. PMid:10300742.

Seddon, J., \& O’Donovan, B. (2010). Rethinking lean service. Management services, 54(2), 14-19.

Selau, L. P. R., Pedó, G. B., Senff, D. S., \& Saurin, T. A. (2009). Produção Enxuta no Setor de Serviços: Caso do Hospital de Clínicas de Porto Alegre - HCPA. Revista Gestão Industrial, 1(5), 122-140. http://dx.doi.org/10.3895/ S1808-04482009000100008

Shingo, S. (1996). O Sistema Toyota de Produção - Do ponto de vista da engenharia de produção. Porto Alegre: Ed. Bookman. PMid:8905671.

Silvestro, R., Fitzgerald, L., Johnston, R., \&t Voss, C. A. (1992). Towards a classification of service processes. International Journal of Service Industry Management, 3(3), 62-75.

Slack, N., Chambers, S., \& Johnston, R. (2002). Administração da Produção (2. ed.). São Paulo: Atlas.

Song, W., Tan, K. H., \& Baranek, A. (2009). Effective toolbox for lean service implementation. International Journal of services and Standards, 5(1), 1-16. http://dx.doi. org/10.1504/1JSS.2009.021663

Staats, B. R., \& Upton, D. M. (2009). Lean Principles, Learning, and Software Production: Evidence from Indian Software services. Working Paper. Harvard Business School.

Swank, C. K. (2003). The lean service Machine. Harvard Business Review, 123-129. PMid:14521103.

Venkat, K., \& Wakeland, W. W. (2006). Using Simulation to Understand and Optimize a lean service Process.

Womack, J. P., \& Jones, D. T. (2003). Lean thinking. Simon \& Schuster.

Womack, J., \&t Jones, D. (2003). Lean Thinking, Banish Waste and Create Wealth in Your Corporation (rev.). Free Press.

Womack, J. P., \& Jones, D. T. (2005). Lean Consumption. Harvard Business Review, 83(3), 58-68.

Womack, J. P., Jones, D. T., \& Roos, D. (1992). A máquina que mudou o mundo (14. ed.). Rio de Janeiro: Campus. 